Article

\title{
Bringing the Community Back: A Case Study of the Post-Earthquake Heritage Restoration in Kathmandu Valley
}

\author{
Stelios Lekakis $1, *(\mathbb{D})$, Shobhit Shakya 2 (1) and Vasilis Kostakis ${ }^{2,3}$ \\ 1 McCord Centre-School of History, Classics and Archaeology, Armstrong Building-2.44, \\ Newcastle University, Newcastle upon Tyne NE1 7RU, UK \\ 2 Ragnar Nurkse Department of Innovation and Governance, Tallinn University of Technology, \\ Akadeemia tee 3, 12618 Tallinn, Estonia; shobhit.shakya@ttu.ee (S.S.); vkostakis@cyber.harvard.edu (V.K.) \\ 3 Berkman Klein Center for Internet \& Society, 23 Everett St, Harvard University, Cambridge, MA 02138, USA \\ * Correspondence: stelios.lekakis@ncl.ac.uk
}

Received: 5 July 2018; Accepted: 31 July 2018; Published: 7 August 2018

check for updates

\begin{abstract}
Heritage preservation is a resource-intensive activity nested among other processes in the public administration, related to identity building and touristic product enhancement. Strategies and schemata associated with heritage preservation sprang in the western world after WWII and they have been adapted, in the form of 'heritage management', in various contexts with questionable effectiveness regarding sustainability. Our paper discusses the case of the post-earthquake cultural, social and political landscape of the World Heritage Site of Kathmandu valley in Nepal. By reviewing the bibliography and drawing upon various case studies of post-earthquake heritage restoration, we focus on the traditional ways of managing human and cultural resources in the area as related to the modern national heritage management mechanism. We also examine how traditional practices, re-interpreted into a modern context, can point towards inclusive and sustainable forms of collaboration based on the commons. We shed light on the elements of an emerging management system that could protect the vulnerable monuments through community participation, adapted to the challenging realities of the Nepalese heritage and its stakeholders.
\end{abstract}

Keywords: heritage management; commons; restoration; Gorkha earthquake; living heritage; traditional knowledge

\section{Introduction}

The disastrous Gorkha earthquake of 2015 disrupted development in Nepal, and brought about challenging issues concerning the restoration of the UNESCO (United Nations Educational, Scientific and Cultural Organisation)-acknowledged heritage of Kathmandu Valley. This raised questions surrounding whether it is sustainable to employ a mainstream western-based approach, which treats heritage as any other resource that should be protected, and invests through a top-down scheme. Or should there be a community-based alternative, premised on the socio-religious past of Kathmandu Valley? Based on a discussion of heritage as a project developed and nested in the public life of modern nation-states, especially after WWII, this paper discusses both scenarios unfolding in different case studies in Kathmandu Valley. We then opt for a third option, particles of which are already present in contemporary Nepal. The third option should be based on an extended community participation scheme, built upon concepts from the 'social turn' of the western approach in heritage management towards a commons-based governance for heritage. 


\section{Governance, Community Participation and the Commons}

In the social sciences, governance is a neutral concept that covers three sectors: Public, private, and the non-governmental sector [1]. According to Stoker [2], governance is about an autonomous self-governing network of actors, while the government's role is to steer and guide rather than to command and exercise full authority. Therefore, governance, i.e., the act of creating conditions for ordered rule and action, comes from multiple actors that also involve non-state actors [2-4]. Citizen participation and empowerment is thought to be nourishing democratic values [5]. In the case of local governance and management of local resources, the involvement of local communities is crucial and has found its place in various political agendas [6,7]. Community involvement has been a critical focus in mainstream discourses of several disciplines, bringing about terms such as 'co-production' that has lately become a buzzword [8-11].

Concerning community-driven governance of resources, the concept of the commons has been popular ever since Ostrom [12] reinvigorated the interest in it, answering to the proponents of the 'tragedy of the commons' discourse, promoted by Hardin [13]. Ostrom's ethnographic work has documented the feasibility and the potential of systematic and sustainable management of natural resources, outside the state and/or the market, towards a sustainable and just future for the communities involved [12]. Since then, there have been several scholars who have contributed to the vast amount of literature concerning the 'commons' [14,15].

When concerning developing countries and especially the South Asian region, the communities are strong while the governments are weak. However, in several cases, they lack capacity but not the ability of impactful action [16]. In these settings, communities have an even more pivotal role. Nevertheless, governance does not have a global standard, especially when communities are concerned; where the background is set by the local cultures, ideas, and practices. Drechsler [17] argues that there are at least three paradigms in public administration and governance based on theories and potentiality, namely: Global-western; Islamic; and Confucian. Buddhist governance has been pointed out as a fourth paradigm. In parts of Asia, public administration models based on non-western influences have been, in cases, as effective as models based on global-western best practices. While some of these models have been authoritarian some have been more inclusive in terms of community participation. There are several cases where non-western traditions have influenced participatory models in local governance [18-20]. However, regions that do not share a common historical background may not always have the same trajectory in the development of governance practices. Thus, it becomes essential to look into each context with a different perspective; acknowledgment of the different paradigms in public administration and governance enables us to do so. For the case of Kathmandu Valley, discussed in this paper, we look at the local traditions based on non-western, public administration and governance paradigms. Kathmandu Valley has been highly influenced by Buddhist traditions historically that still continue to influence most aspects of contemporary life [21,22].

\section{The Concept of Heritage and Its Management: A Western Perspective}

Cultural heritage is a by-product of modernity [23]. Its development coincided with the emergence of the nation-states in 18th and 19th centuries in Europe, as these new collective political subjects configured socially significant sites, buildings, landscapes and personalities into national identity landmarks [24].

This cultural heritage mechanism was built on a pattern introduced in the Renaissance and the Enlightenment; that of distancing the past from the present day in an observable place that could be studied to reveal itself. The official narratives that would bridge the distance with the reclaimed present constituted national histories; the overarching truth for the birth and the survival of the nation-state's soul and values through the centuries $[25,26]$. These narratives were anchored on and illustrated by the tangible remains of the past, monuments that were recast as national treasures. In this way, nation-states, amongst the other rational management processes and monopolies, they also took up the role of selecting ancestors and enclosing significant features and figures in an elective national narrative 
for the benefit of their people, connoting unique and exceptional links with a glorious ancestor, in an unbreakable continuum.

Heritage management, as a cohesive way of dealing with the remains of the past and a scientific branch, came up after the end of the WWII, along with the attempt to work together and ameliorate the trauma left open in Europe and the rest of the world. Championing the need for a new, shared and somehow neutral field for collaboration and diplomacy, international organisations were established (for example, UNESCO 1945; ICOM (The International Council of Museums) 1946; ICCROM (International Centre for the Study of the Preservation and Restoration of Cultural Property) 1956; ICOMOS (The International Council on Monuments and Sites) 1965), focusing on culture and heritage, introducing at the same time an arena of cultural policies that would progressively evolve in what we identify today, as the 'cultural industry' $[27,28]$.

The new discipline borrowed processes from management and business administration shaping the basic tools of heritage management in action (for example, management plans, assessment and monitoring protocols) but also theoretical concepts (for example, values, stakeholders), customised to apply in a heritage context. Elaborated tools also came from natural resources management, as the concept of heritage as a 'resource' or the goal of sustainability in its management $[29,30]$.

In this framework, normative documents (charters, directives, documents), organised by intergovernmental organisations, aspired to foster collaborations and promote good practices in cultural management. In the 1960s and 1970s, they focused on the protection of "authenticity and integrity" of cultural heritage for the benefit of the "humanity" [31,32]. It seems that priority was given mostly to the physical carrier of the monuments, their original material. Following the 19th century dialectics, they emphasised on the internal values of heritage that are always tactile, static and eternal, can be estimated (age, rarity) or appraised aesthetically (monumentality, artistic merit) [33]. In this way, the significance of a monument was reflected in its historical value and its levels of preservation, as it was curated and stewarded by professionals (archaeologists, architects, conservators) working for the state services; their main intention was to protect the 'cultural property' for the perpetuation of the national values and the development of the cultural product as a touristic output [34].

\subsection{The Social Turn and Heritage Governance}

However, the 1970s marked a turn in these heritage management narratives, focusing on more social objectives. The network of heritage stakeholders is broadening towards a more decentralised pattern, involving apart from the experts and the national authorities, various communities with vested interest in heritage, examining variable values to assess the significance that lies outside the materiality of the monuments. It is no wonder that at that time the concept of 'governance' is also introduced in heritage literature, implying a broader and not a priori top-down management process of cultural resources $[30,35,36]$.

We can trace the beginning of this social turn to the Burra Charter, the first version of which was adopted in 1979 by Australia ICOMOS [37]. This document focused on the understanding of heritage significance as a process, reflecting the ways it is being formed inside a living society, thus opening up the platform of heritage management to a number of interest groups, the visions, and ideas of which should be taken into consideration at all stages of the heritage management process (research, planning, implementation, evaluation) [38].

Later normative documents developed this pattern and its economic overtones [39,40], as for example the Faro Convention that highlighted the importance of participation for the communities and the need to acknowledge the values they attach to objects and places, towards management processes that apart from historic material preservation, do good to the people as well [41]. This offered a higher level of inclusion and reflective control over heritage governance but also introduced new hybrid heritage categories, as the landscape or the intangible heritage, that reside in more locally based and nuanced understandings than the national dialectics for heritage [42,43]. 
The political and economic scenery in Europe had been the perfect background for these developments, especially with the emergence of neo-liberalism and the establishment of the new public management; in this context, heritage was treated as another 'resource', understood in terms of stock and flow, an input in the economic circle of the state, as the physical capital a few decades earlier that needed to be governed as any other national asset, respecting the funds provided by the average taxpayer $[27,44]$.

\subsection{The Concept of Sustainability and Its Implications on the Heritage Governance Discourse}

These two relatively new aspects in heritage management, the drive for broader participation and the economic connotations, are combined in a novel concept that is being introduced in the late 1980s [45]. The framework of sustainability derived from the worrying observations of the impact of growth with short-term planning to the physical environment but also to the social cohesion and the economic viability $[46,47]$. It emphasised on the need to cover human development goals, without undermining the availability of resources and the integrity of society for the future generations.

Culture was recognised as an essential attribute in this process. Translated into another form of a homogenised capital, aside to the human, physical or indeed economic, culture was deemed as a strategic element and a dynamic input in this form of equitable and considerate development. Acknowledging its contextual and coordinating aspects, culture was even suggested by UNESCO and the United Nations as a new circle in the centre of the sustainability Venn diagram [48].

In the sustainability scheme, public participation was also considered vital in order to amplify capacity building inside communities [49] but also to ensure the viability of future policies [50,51]; both aspects widely reiterated in a number of international documents that followed.

In any case, sustainability discourses transformed and keep shaping the dialectics and practices of heritage management around the world, appearing in various forms: As the viability of actions and pathways of action, as the purpose of heritage conservation, as urban regeneration or as the goal of cultural tourism [44]. Furthermore, they also redirected the focus to the local level, the main grounds for participation, where resilient knowledge and practices could provide new understandings and modus operandi for the viable management of the available resources.

\section{The 'Indigenous Mind-Set'}

This refocusing to the local level was paradigmatic in the-recently then-decolonised countries but also in "crypto-colonies", as Thailand, Afghanistan, Greece and Nepal [52] or relevant places romantically considered spared by modernity. Postcolonial criticism together with attempts to emancipate local/indigenous people focused western attention on the 'indigenous mind-set', a supposedly untapped resource that could provide alternative pathways to the sustainable management of local resources, 'as it was done for hundreds of years'.

In a nutshell, the indigenous mind-set can be considered as systems of knowledge, constituted of collectively learned experiences on traditional technologies, social, economic and philosophical learning that explain the world and are grounded in spirituality, practices, and ways of being in nature [53]. These processes conveyed by experiential learning and oral traditions, storytelling, and other means of intangible record keeping, can be juxtaposed to the western, positivistic modes of structuring knowledge, and communicating it through formalistic education practices.

Particles of these traditional systems have been severed from context and appear in literature lately, bundled as 'Traditional (Ecological) Knowledge' or 'Indigenous Knowledge' —which can potentially provide insights on archaeological sites, medicinal properties of plants, sustainable harvesting practices, wildlife monitoring, environmental change, behavioural ecology, etc. [53]. The indigenous mind-set is also being introduced in traditional curricula at a university level [54] or even taught through Massive Open Online Courses, offering concise explorations on indigenous worldviews, pre-contact social systems and traditions, resistance patterns and self-governance (See, for example: https:// 
www.coursera.org/learn/indigenous-canada; https://www.edx.org/course/reconciliation-throughindigenous-education; https: / /www.coursera.org/learn/aboriginal-education).

The same trend became visible in heritage management at an early point. The Nara document of authenticity, in the spirit of the Burra Charter, challenged the western obsession of material authenticity. It discusses conservation methods that could substitute the physical carrier of monuments but preserve their essence, through the survival of the traditional building/conservation techniques and the communities that sustain them [55]. The Nara document in 1994 (as the Burra charter earlier) can be considered as spill over of "indigenous archaeology" practices. This is developed for the agenda of incorporating the indigenous population in the economic, social and political life of the state with a cultural agenda, and inbuilt criticism of the western management perspective [56-58].

Appreciation and adaptation of indigenous systems in heritage management are nowadays a steadily upcoming field. In 1998 East Rennell in the Pacific Ocean was inscribed on the World Heritage List "under customary land ownership and management" [59], affirming the significance of non-western management systems, transcribed though in the western concept of a UNESCO World Heritage Site inscription [60]. A pattern observed again in the management plans of Kakadu \& Uluru Parks in Australia through the involvement of the indigenous communities [30,61].

In the same climate, ICCROM has been promoting in the last years the 'living heritage' model, developed for sacred sites of South-Eastern Asia. This model prioritises the living dimension of heritage that reflects the original function, still served by communities dwelling near or inside the ancient structures, forming an integral constituent of the site [62,63]. Apart from the edifices, it also aims at the preservation of oral traditions, skills, and knowledge, performances and rituals related to the site cf. [30,42].

The latter reflects another pattern acknowledged in the indigenous mind-set agenda for the sustainable management of heritage. Heritage crafts and skills, such as traditional methodologies for preserving heritage but also producing new artisanal goods based on traditional forms, are a new niche market in the creative economies, with considerable impact and profits.

\section{The Case of Nepal}

\subsection{Research Methods}

After critically reviewing relevant literature on heritage, governance, and sustainability, we now turn to the discussion of the Kathmandu Valley World Heritage Site. The case of Kathmandu Valley provides an interesting insight into a non-western perspective of heritage governance. Kathmandu Valley is a historically significant settlement, arguably a paradigmatic case-study for studying the South Asian region in the past [64]. The traditional governance mechanisms in the Valley have been highly influenced by Buddhist traditions, extending in the field of heritage governance, as we will explore below.

The recent earthquake in 2015 caused great losses to heritage structures $[65,66]$. The scale of the damage and the reconstruction required provides an interesting context to discuss governance and the emerging stakeholders in heritage management. To do this, this study draws upon multiple courses of information, including bibliographic and archival sources, local press publications, and ethnographic data-semi-structured interviews with engaged stakeholders (community members, government representatives, and local experts). We also use participant observation from several case studies, which are part of ongoing research by one of us that will culminate in a doctoral thesis.

\subsection{Historical Context}

Nepal has been known for its art, architecture, and culture ever since Brian Houghton Hodgson introduced the country to the West during mid-1800s. Historical monuments mostly concentrated around Kathmandu Valley have been well studied for their architectural uniqueness [67-69]. Cultures of Kathmandu valley and the Newars. Newars, or Newa, are a socio-linguistic group, who during the 
pre-Shah era where the citizens of Nepalmandala or the system of cities in and around Kathmandu Valley before the unification of modern Nepal. They are often falsely identified as a caste group [70,71], and are especially distinctive in their amalgamation of Buddhist and Hindu influences within a very urban socio-cultural setup [72,73]. Kathmandu Valley was inscribed in the UNESCO World Heritage List (four years after the list's establishment) as an exceptional testimony to the architecturally explicit, local civilization of coexistence of Hinduism and Buddhism. The inscription résumé highlights seven important sites in the Valley: Durbar Squares of Hanuman Dhoka (Kathmandu), Patan and Bhaktapur, the Buddhist stupas of Swayambhu and Bauddha, and the Hindu temples of Pashupati and Changu Narayan [74].

Characteristic of the Newar architecture is the pagoda style, believed to originate in Kathmandu Valley and exported to China during the Yuan dynasty by the Nepali artisan Araniko [75,76]. These monuments (of which there are more than a thousand in number) exist within the three major and other minor historical towns in and around Kathmandu, where since more than a millennium an urban society was formed and continues to exist even nowadays [69]. Within the scheme of the traditional urban socio-cultural setup, a framework for community governance that is characterised by community organizations called Guthi existed, a core feature of the Newar society.

Guthi is a unique institution among Newars that historians believe to have existed since the Lichhavi era (400 to $750 \mathrm{CE}$ ), appearing as Gosthi in older historical accounts [72,77]. The oldest palm-leaf manuscript written in Newari (Language spoken by the Newars now officially called Nepal Bhasa.), dated in $1114 \mathrm{CE}$, explained the rules and regulations for collective use of the property of a Buddhist Monastery among the Guthi members [78]. Guthis have had several functions within the Newar society, and they are still an integral part of Newar lifestyle. Guthis have been categorised in many ways by writers who have studied them [79-81]. In general, based on the goals or objectives, Guthis could be discerned in three types, concerning: (a) The organisation of festivities, workshops, teaching craftsmanship, playing music, maintaining water conduits and other social tasks; (b) funeral preparations and (c) purely religious activities (as most Guthis consist of a specific caste or group within the Newar society.). Guthis, while being part of the intangible heritage of Newars, were also set for the conservation of other heritage resources, such as monasteries, sattal (which are traditional structures common in Kathmandu Valley that serve as public rest houses often used for social gatherings and public occasions), temples (virtually all temples in Kathmandu were looked after by Guthis. Guthis still actively participate in maintenance of major temples such as Baudhha and Swyambhu), and art forms like folk music, devotional dances and plays (most Guthis still play devotional music called bhajan during festivals. Masked dances such as the Kartik Nritya are also performed with involvement of Guthis) [82-84].

Despite the cultural and historical significance of Guthis, in recent past, their role has been dramatically reduced in the state's administrative framework. With the "Guthi Sansthan Act" of 1964 and further amendments in 1976, several Guthis and their functions were incorporated into the state owned Guthi Sansthan corporation while the land that Guthis owned was either nationalised or allowed to be privatised and distributed amongst the Guthis' members [83-85]. With traditional practices considered outdated while following the trend to copy global mainstream governance and public administration models, the Guthi institution went into decline and solely associated with religio-cultural aspects of the society. In addition, the emerging trend towards a more individualistic lifestyle in the country has dealt another blow at the Guthi institution [86]. With several heritage structures missing their traditional custodians, the effects of the 2015 earthquake were even more disastrous.

\subsection{The 2015 Earthquake and the State Response}

The 2015 earthquake in Nepal reached a magnitude of 7.8 MMS. Its hypocenter was in the Barpak village of Gorkha, and it had a devastating effect on the country, resulting 8674 deaths [65,87]. 
For Kathmandu Valley the losses to architectural heritage were of enormous scale with 753 temples, monasteries and monuments damaged, either partially but significantly or entirely [66].

Nepal, being in a seismic zone, has faced large earthquakes almost every century of its long history [88-90]. During the 2015 earthquake the country was in an already vulnerable condition, as it was in the middle of political transition, and was not prepared for disaster of this size [91]. Furthermore, until 2006, the country had also been in a decade-long civil war $[89,90]$. Following the peace processes and the subsequent transition into a Republic from a Constitutional Monarchy, the country was still politically unstable and economically volatile. Local elections had not been held for almost two decades [92], and the competency level of the government in most aspects was low. The earthquake left the country with a daunting task of reconstruction. Early steps were to turn to international aid, through which different donors pledged more than $\$ 4$ billion [93]. The government also established a public body, the National Reconstruction Authority (NRA) to oversee the reconstruction and distribution of aid to the affected. The heritage reconstruction processes were planned and monitored by a committee that involved the NRA, the Department of Archaeology (DoA) and the local municipalities.

The usual mechanism for infrastructure development in the country was based on closed tender bidding from contractors for which the bids were selected based on the lowest cost method [94]. The DoA and NRA together with the municipalities, which at the time did not have any elected representatives, proceeded with several restoration projects with the available lowest bid tender process mechanism. However, this led to questionable results since the quality of the restoration became a secondary criterion while most contractors lacked sufficient knowledge of the traditional architecture and building techniques, which were essential for keeping the integrity of the heritage structures. As a consequence, several of the major restoration projects were suspended due to pressure from the local community or intervention from DoA for reasons, such as the use of inappropriate building material or techniques $[95,96]$. Furthermore, almost all of the restoration projects became battlegrounds between the key stakeholders, seeking to resume control. In most cases the communities did not trust the government-appointed contractors, and demanded more direct involvement in the restoration process [97].

\subsection{Other Stakeholders}

Since the inscription of Kathmandu Valley in 1979 [74], UNESCO has been a significant stakeholder in the restoration projects, as in the Kasthamandap sattal case in Kathmandu durbar square and the Rani Pokhari with the Bal Gopaleswor temple in its premises [98]. UNESCO has a significant influence on cultural heritage maintenance and restoration through the Kathmandu Valley Preservation Trust (KVPT). KVPT was founded in 1991 by Eduard F. Sekler, who was the team leader of the UNESCO Campaign to Safeguard the Cultural Heritage of the Kathmandu Valley [99]. Therefore, KVPT can be understood as an expert organization with close ties to UNESCO. All restoration projects are directed chiefly by Dr. Rohit Ranjitkar, who is a noted expert in heritage conservation in the context of Nepal. KVPT had a partnership with the local government and the DoA for maintenance and restoration of important structures in Patan Durbar Complex. The KVPT has restored structures such as the Sundari Chowk wing and North Taleju temple of the Durbar complex. The organization has a good reputation among donors and is currently being funded by several international agencies such as the US Ambassadors Fund for Cultural Preservation, the Japanese Embassy in Nepal and the British Embassy among others [100].

Contrary to the influence of KVPT and UNESCO in the Patan Durbar area, the case is entirely different in the Kathmandu Durbar Complex. Having been the traditional seat of the Nepali Monarchy, the Durbar Complex had been more closely monitored and controlled by the government. This might explain the fact that the restoration projects of two of the significant structures in the area have been directly handed to China and the US through diplomatic level agreements. The nine-storey tower of Basantapur durbar square was restored by Chinese experts while Gaddi Baithak by funds from the U.S. Ambassadors Fund for Cultural Preservation, which has partnered with Miyamoto Global Disaster 
Relief (both American non-profit Organisations) and ICOMOS. ICOMOS is a non-governmental international and professional organisation, dedicated to the conservation of architectural heritage. Founded in 1965, ICOMOS is one of the three formal advisory bodies to the UNESCO World Heritage Committee, along with IUCN (the International Union for the Conservation of Nature) and ICCROM [101,102].

The Kasthamandap sattal in the same area, however, received a different treatment given the function of the structure; a public rest house, commonly used by the community and its ownership claimed by the local community and Guthis [103-105]. The maintenance of the monument was based on the Buddhist tradition, where communities volunteer to take care structures as an act of charity [106-108]. Major renovations, however, took place in 1966, organised by the government [109]. Since then the local authorities had maintained the ownership of the building but the local Guthis and community groups continued to use the structure for traditional and other social events. After the earthquake the delay in the reconstruction process and also the mistrust towards the local authorities led the community to self-organise and create a locally based entity, focusing on the reconstruction of the sattal. Consequently, on 25 April 2017, the 'Campaign to Rebuild Kasthamandap' was launched by the local community in the area and on 12 May a four-way agreement was signed between the NRA, DoA, the Municipality and the Campaign, handing over the responsibility of rebuilding Kasthamandap to the Campaign [97]. UNESCO and other international bodies have supported the move. Thus, an excavation was organised and carried out by DoA, Durham University and UNESCO that dated the structure as early as 700 CE [104]. However, after the local elections in 2017, the newly elected local government withdrew from the agreement and insisted on taking over the reconstruction through contractors selected by the Municipality [97]. After a lengthy dispute between the community and the Municipality, a new committee was formed in May 2018, chaired by a Provincial Assembly member from the area, Mr. Rajesh Shakya, and the reconstruction process resumed with the involvement of the community participants, even though not everyone from the initial Campaign was included [110] (Figure 1).

The model applied to Kasthamandap was not very different from the models for community participation in heritage restoration used in Kathmandu Valley for other monuments. The first project that highlighted community initiative is the restoration of Ashok Chaitya in Thamel, which is a popular tourist area in Kathmandu [111,112]. The restoration was attempted before the earthquake, but due to the disastrous event, the project needed to restart. The project was headed by a local resident, Mr. Sanjeeb Shrestha, who took the initial steps to start the project when a Chinese monk showed interest in the restoration of the Buddhist monument. The damage caused by the earthquake provided more stimulus. Since the old Guthi which took care of the stupa was defunct, a new committee was formed and registered at the municipality office with some members from the old Guthi involved and commenced the restoration with a permit from the municipality. By June 2017, the monument was already completed and a stone inscription with the name of all the donors was added on 4 July 2017. Through partial funding from the municipality and other donations the committee collected Rs $3,629,345$ of which Rs. 2,998,375 were spent and the rest saved for future maintenance. Except for the donations, there was voluntary participation from the local community while also artisans worked for a discounted rate. As claimed by the committee, the project budget was half of the initially estimated (Figure 2). 


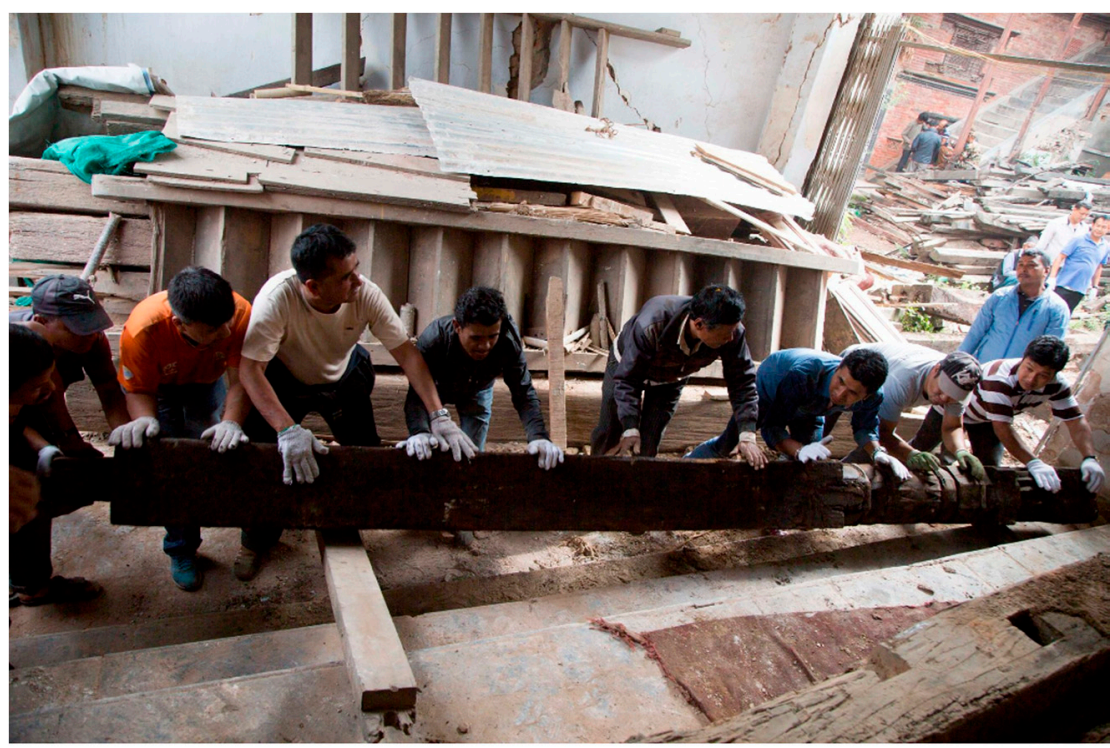

Figure 1. Volunteers working to move salvage crafted wooden pillars from the wreckage of Kasthamandap for proper storage (Source: Sandesh Munikar and Kasthamandap Reconstruction Committee).

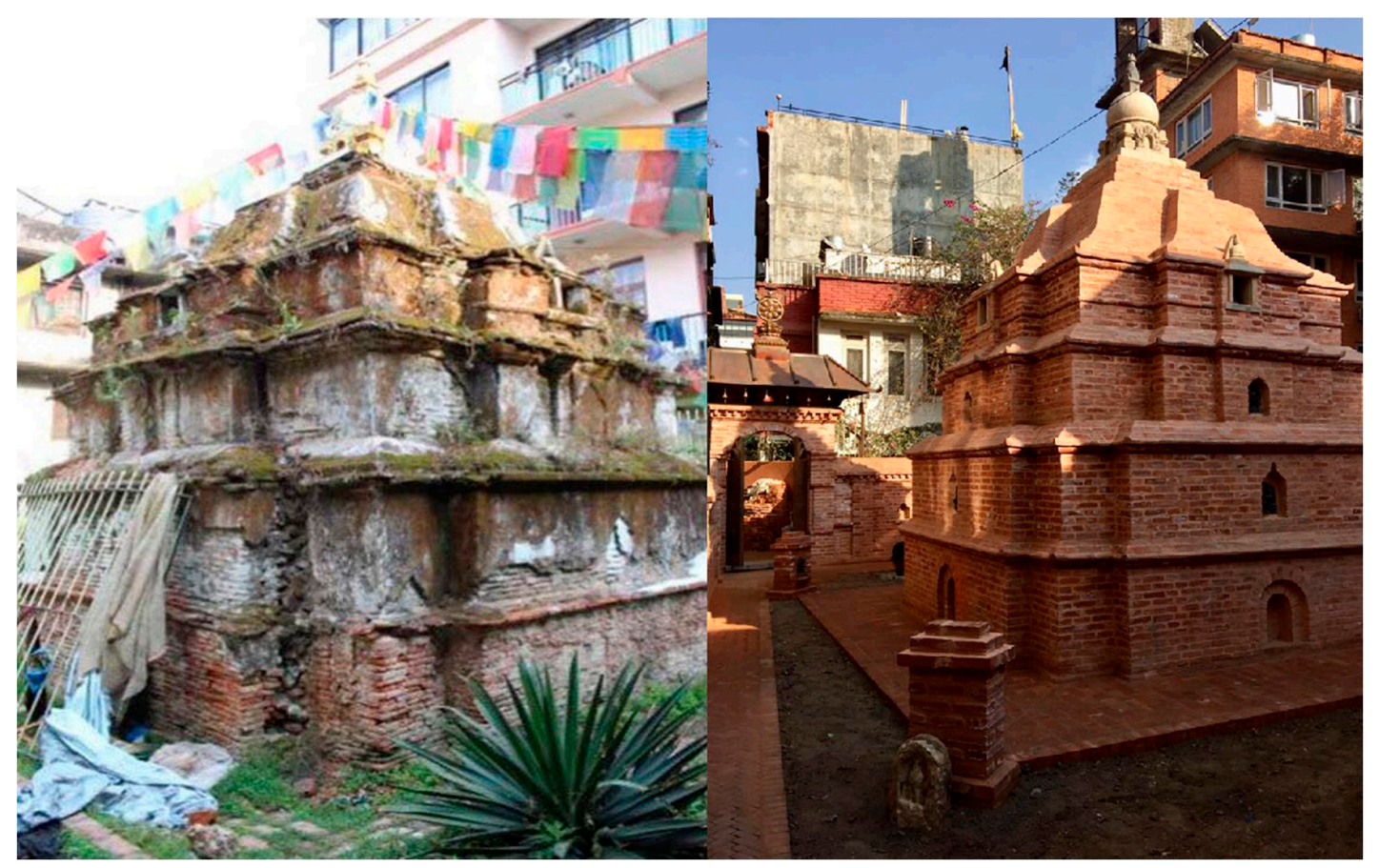

Figure 2. Thamel Ashok Stupa before and after renovation (Source: Ashok Vihara Restoration and Conservation Committee).

Reviewing the cases of Kasthamandap and the Thamel Ashok Stupa, a trend can be acknowledged pointing to a working model for stakeholders' involvement and community participation in heritage management, as a result of the 2015 earthquake in Nepal. There are several more projects that have progressed using similar models for community participation after the earthquake; such as, the Jaya Bageshwori, the Bauddha Stupa, and Maitripur Mahavihara. Three main reasons tend to be considered as catalytic for the development of this trend: Firstly, the inadequacy and ineffectiveness of the government mechanism concerning the restoration projects from the communities' viewpoint. 
Secondly, an apparent influence from UNESCO and international agencies exists, and this has multiple implications. In Patan Durbar complex an "expert approach" has been initiated by KVPT, whereas in the case of Kasthamandap, the Campaign agenda was based on the Guthi spirit $[97,105]$. Indeed, the third main reason is that the community involvement is strongly influenced by the Guthi institution and Buddhist modi operandi that is deeply rooted within the traditions of the Newar society and continue to affect people lives in the public sphere.

\section{Reviewing the Context}

Heritage is often considered as a western construct, based on the significance of material authenticity and bearing underpinnings related to national identities and the touristic prospect through a top-down management process. This paradigm and its widespread adaptations in non-western contexts have been shifting the last three decades, towards a more socially inclusive and sustainable pattern, using a series of re-appropriated indigenous management tools.

However, in Nepal, there seems to have been a slightly different trajectory in managing the material remains of the past. Traditionally, pre-modern community involvement models have adequately cared for historic structures. With attempts to modernise public administration in the country, these traditional models were increasingly ignored. Implementation of models mirroring western heritage practices has not been entirely successful. The devastating Gorkha earthquake has highlighted and intensified problems in the process. It has added a new chapter in Nepal's cultural history but also revealed the new realities of governance capacity and concerns about the future of heritage conservation in the country. In these precarious circumstances, two obvious options emerge: To further cultivate the western approach to heritage management towards a more systemic adaptation in Nepal or to tap into the available social capital and revive traditional patterns of heritage conservation through community participation. At the same time, the question of sustainability, regarding resources, processes (derived from the western heritage or the 'indigenous' context) and goals remains.

As we have examined, the western approach to the post-earthquake conditions brought about a series of problems. Restoring and reconstructing historic buildings is getting increasingly expensive in Nepal, causing commercial contractors to use cheaper, non-traditional materials and lobby for design alterations that would grant them further profits. Parallel to that, NGOs-as KPVT-rely on foreign aid and focus on projects that would attract donors. Their focus revolves around the seven highlighted sites, main attractions for tourists, even though the whole of Kathmandu Valley has been inscribed in the World Heritage List. As a result, priority of foreign aided projects appear always to be the same sites while all the other monuments come second. Moreover, relying exclusively on foreign aid does not seem as a sustainable choice. Thus, an effective management system based solely on the western mandates, i.e., through commercial contractors or NGOs specializing in heritage conservation, is not plausible.

Considering the second option, traditional models are still active in Nepal, as several Guthi organizations; the case of Maitripur Mahavihar demonstrates that. However, as Nepal moves into modernisation, only a fraction of these survive and are still useful, while their capacity to handle large-scale projects is questionable. The possibility of enhancing these Guthis is not high as the state does not have a mechanism for it and would not allocate further resources on the revival of pre-modern institutions. But even in this case, with Guthi owned lands either privatised or nationalised and primarily deprived of their support community, the Guthi institution cannot anymore be self-reliant or able to face the contemporary socio-political challenges in Nepal.

\section{Ways Forward}

The circumstances examined above suggest for a third option: To bring together the various ideas and practices in play in the post-earthquake Kathmandu Valley, and create a hybrid model. Such a 
model would embody the spirit of traditional community-oriented practices and also the paradigm shift towards the 'social' mode in the western heritage management patterns.

As the case studies show, there is encouraging participation from key stakeholders including the state, non-state and international agents and a trend towards a more inclusive attitude in conservation attempts. Guidelines for a broader participation scheme are abundant in the bibliography and normative documents $[38,41]$ along with case studies of community involvement in natural and cultural conservation plans [113-115].

However, directives should be based on and adapted to the context of Nepal. In our case, a focus on the transparency of the agendas from all sides is necessary. Discussions and decision-making processes should be organised and facilitated to minimise corruption. In this process, there will be also need for the national/local authorities to shed some control in the heritage management mechanism and thus aid community empowerment. In the cases discussed, this potential was met when supported by the NGOs in the field; a fact reinforcing the argument in favour of plural participation in the heritage governance scheme.

The influence of the western patterns and traditional tools in heritage management (e.g., management plan, value assessments) should also be scrutinised. These tools carry normative heritage understandings, meaningful from a western perspective but not compliant with other socio-political contexts with different priorities and needs [30]. The same applies to tools coming from western discourses of the 'indigenous mindset' that are often de-contextualised and entangled in systemic power imbalances. They come with the social evolutionist tinge of the 19th and 20th centuries from shady 'noble savages', representatives of our 'primitive' human past, possessing knowledge to remedy the adverse effects of modern living. They might offer input to the established processes of research or monitoring. However, they should also be critically examined. Indigenous knowledge systems and western science are couched in very different languages. In contrast to western knowledge, which tends to be text-based, reductionist, hierarchical and dependent on categorisation, indigenous thought does not strive for a universal set of explanations. On the other hand, it is particularistic in orientation and often contextual $[53,116]$.

Following on the lessons learnt after the Burra charter and Nara document, mix and match practices with western approaches and traditional systems in heritage governance can be problematic. These commonly breed inequality and promote the dominance of the most relative to the frame each project is being developed. For example, the 'living heritage' model, a supposedly middle ground, evangelises the capitalisation of local/indigenous know-hows towards a sustainable management pattern. However, the participation methods involved do not address the hidden power imbalances, as the role of the core community and the western management concepts, conveniently serving as the framework of the whole project [30].

Moreover, combined tools focus tactically on the immediate issue in question without working towards broader emancipation goals. For example, in jointly managed national parks in Australia, indigenous majorities on management boards are now a well-established approach [61,117]. However, the idea of having indigenous people as majority decision-makers over urban development options or metropolitan-scale strategic planning in Australia is largely unthinkable [118].

\section{Towards a Commons-Based Governance for Cultural Heritage}

Lekakis [119] argues that to define cultural heritage, one must consider five interrelated components: (1) The physical material, e.g., a temple, its stones; (2) the communities and their values that are local and distant related stakeholders, e.g., archaeologists, tourists; (3) the knowledge and information produced, e.g., scientific studies related to our temple; (4) the past and present social knowledge, e.g., local beliefs, practices and visions; and (5) the relevant services, e.g., tourism.

Therefore, the sustainable future of the cultural heritage a hybrid pattern of governance is necessary that would employ context-specific tools and methods, already at play in the case of the Kathmandu Valley. Nowadays, the national enclosures of the past-in the form of heritage-are 
acknowledged and challenged in various local, national or international levels. We argue that the heritage, the collective values inspired by it, the knowledge produced or surviving, and the services involved in its communication, should be acknowledged as commons, in the way Ostrom [12,120] and others [121,122] discuss natural and information resources.

Given this volatile paradigm that emerges, heritage is perceived as a resource-intensive affair that cannot be solely managed by national authorities. Firstly, because of the administrative competencies. Secondly, because heritage embodies a variety of transient values and aspirations of the communities it represents, calling for self-governing institutional arrangements and bottom-up decision making. In this schema, strategies developed should be much more than the collation of western tools in context, as everything should be customised through plural participation and not driven by national or personal agendas.

In the case of Kathmandu Valley, the (western-oriented) public administration model of Nepal along with UNESCO set a few boundaries. The government agencies, the local municipalities, UNESCO and the community that include Guthis and NGOs manage the specific heritage components variably. We argue that they should collaborate and organically develop commons-based governance schemata and strategies. Such a commons-based governance model should consider all the components described above.

There is a very rich substratum of knowledge produced in the past and considerable scientific knowledge being produced nowadays by various communities that are mobilised around the World Heritage Site (e.g., Guthis and experts from Durham University). State authorities and NGOs and the other stakeholders need to help in the conservation/restoration, after acknowledging the historic context (Guthi patterns) for the preservation of the buildings but also the western context (new technologies and adequate material). Moreover, knowledge produced must be open, available commons-based licenses (e.g., Creative Commons), and thus accessible to the communities related to the project.

Besides the tactical approaches to foster a participatory heritage governance system in Kathmandu Valley, it is apparent that a new theoretical framework for the management of cultural heritage should be systematically established. A shift towards commons-based governance schemata might be the only sustainable solution for the preservation of resources, but also for the complex social and historical values they represent in the various communities. Inscribed under the criterion III and VI in the World Heritage List, therefore having the social implications and the traditional aspects of management acknowledged, this could be the only viable way to preserve the fabric and the (ever-changing) essence of the cultural heritage.

Author Contributions: This article was a collective work: Conceptualization, S.L. and S.S.; Methodology, S.S.; Investigation, S.S.; Writing-Original Draft Preparation, S.S. and S.L.; Writing-Review \& Editing, V.K., S.S. and S.L.; Funding Acquisition, S.S. and V.K.

Funding: The APC was funded by Estonian Ministry of Education and Research grant number IUT (19-13) and McCord Centre, Newcastle University.

Acknowledgments: We are grateful to two anonymous reviewers who provided insight that greatly assisted in the research. Vasilis Kostakis and Shobhit Shakya acknowledge financial support from IUT (19-13) and B52 grants of the Estonian Ministry of Education and Research.

Conflicts of Interest: The authors declare no conflicts of interest.

\section{References}

1. Drechsler, W. Governance, Good Governance, and Government: The Case for Estonian Administrative Capacity. TRAMES J. Humanit. Soc. Sci. 2004, 4, 388-396.

2. Stoker, G. Governance as Theory: Five Propositions. Int. Soc. Sci. J. 1998, 50, 17-28. [CrossRef]

3. Peters, B.G.; Pierre, J. Governance Without Governing: Rethinking Public Administration. J. Public Adm. Res. Theory 1998, 8, 223-243. [CrossRef] 
4. Rhodes, R. Governance and Public Administration. In Debating Governance; Pierre, J., Ed.; Oxford University Press: Oxford, UK, 2000; pp. 54-90.

5. Fung, A.; Wright, E.O. Deepening Democracy: Innovations in Empowered Participatory Governance. Polit. Soc. 2001, 29, 5-41. [CrossRef]

6. Kearney, J.; Berkes, F.; Charles, A.; Pinkerton, E.; Wiber, M. The Role of Participatory Governance and Community-Based Management in Integrated Coastal and Ocean Management in Canada. Coast. Manag. 2007, 35, 79-104. [CrossRef]

7. Sullivan, H. Modernisation, Democratisation and Community Governance. Local Gov. Stud. 2001, $27,1-24$. [CrossRef]

8. Fenwick, T. Co-Production in Professional Practice: A Sociomaterial Analysis. Prof. Prof. 2012, 2, 1-16. [CrossRef]

9. Lember, V. The Increasing Role of Digital Technologies in Co-Production; Working Papers in Technology Governance and Economic Dynamics; Tallinn University of Technology: Tallinn, Estonia, 2017.

10. Van Eijk, C.; Steen, T.; Verschuere, B. Co-Producing Safety in the Local Community: A Q-Methodology Study on the Incentives of Belgian and Dutch Members of Neighbourhood Watch Schemes. Local Gov. Stud. 2017, 43, 323-343. [CrossRef]

11. Vanleene, D.; Voets, J.; Verschuere, B. The Co-Production of a Community: Engaging Citizens in Derelict Neighbourhoods; Springer: Jersey City, NJ, USA, 2017.

12. Ostrom, E. Governing the Commons: The Evolution of Institutions for Collective Action; Cambridge University Press: Cambridge, UK, 1990.

13. Hardin, G. The Tragedy of the Commons. Science 1968, 162, 1243-1248. [CrossRef] [PubMed]

14. Kostakis, V.; Bauwens, M. Network Society and Future Scenarios for a Collaborative Economy; Palgrave Macmillan: Basingstoke, UK, 2014.

15. Bollier, D. Reclaiming the Commons: Why We Need to Protect Our Public Resources from Private Encroachment. Boston Review, 13 August 2002.

16. Migdal, J.S. Strong Societies and Weak States: State-Society Relations and State Capabilities in the Third Wrld; Princeton University Press: Princeton, NJ, USA, 1988.

17. Drechsler, W. Three Paradigms of Governance and Administration: Chinese, Western and Islamic. Soc. Econ. 2013, 35, 319-342. [CrossRef]

18. Blair, H. Participation and Accountability at the Periphery: Democratic Local Governance in Six Countries. World Dev. 2000, 28, 21-39. [CrossRef]

19. Scholte, J.A. Civil Society and Democracy in Cambodia. Glob. Gov. 2002, 8, 281-304.

20. Urinboyev, R. Bridging the State and Society: Case Study of Mahalla Institutions in Uzbekistan. In Norms between Law and Society: A Collection of Essays from Doctoral Candidates from Different Academic Subjects and Different Parts of the World; Lund University: Lund, Sweden, 2011; pp. 115-133.

21. Gellner, D.N. The Emergence of Conversion in a Hindu-Buddhist Polytropy: The Kathmandu Valley, Nepal, c.1600-1995. Comp. Stud. Soc. Hist. 2005, 47, 755-780. [CrossRef]

22. Locke, J.K. Buddhist Monasteries of Nepal: A Survey of the Bahas and Bahis of the Kathmandu Valley, 1st ed.; Sahayogi Press: Kathmandu, Nepal, 1985.

23. Thomas, J. Archaeology's Place in Modernity. Modernism/Modernity 2004, 11, 17-34. [CrossRef]

24. Anderson, B.R.O. Imagined Communities: Reflections on the Origin and Spread of Nationalism; Verso: London, UK, 1991; p. 224.

25. Lowenthal, D. Possessed by the Past: The Heritage Crusade and the Spoils of History; Free Press: New York, NY, USA, 1996.

26. Lekakis, S. The Cultural Property Debate. In A Companion to Greek Art; Smith, T.J., Plantzos, D., Eds.; Blackwell Publishing Ltd.: Chichester, UK, 2012; Volume I.

27. Mourato, S.; Mazzanti, M. Economic Valuation of Cultural Heritage: Evidence and Prospects. In Assessing the Values of Cultural Heritage; Getty Conservation Institute: Los Angeles, CA, USA, 2002; pp. 51-76.

28. Frey, B.S. Evaluating Cultural Property: The Economic Approach. Int. J. Cult. Prop. 1997, 6, $231-246$. [CrossRef]

29. Throsby, D. Cultural Capital and Sustainability Concepts in the Economics of Cultural Heritage. In Assessing the Values of Cultural Heritage: Research Report; Getty Conservation Institute: Los Angeles, CA, USA, 2002; pp. 101-117. 
30. Lekakis, S. To the Splendour of Our Byzantine Heritage. Managing Orthodox Churches in the Island of Naxos. In Naxos and the Byzantine Aegean: Insular Responses to Regional Change. Papers and Monographs from the Norwegian Institute at Athens; Crow, J., Hill, D., Eds.; Norwegian Institute at Athens: Athens, Greece; Volume 7, pp. 371-390.

31. UNESCO. The World Heritage Convention. Available online: https://whc.unesco.org/en/convention/ (accessed on 2 July 2018).

32. ICOMOS. The Venice Charter 1964. In Proceedings of the 2nd International Congress of Architects and Technicians of Historic Monuments, Venice, Italy, 25-31 May 1964; pp. 1-4.

33. Carman, J. Valuing Ancient Things: Archaeology and Law; Leicester University Press: Leicester, UK, 1996.

34. Lekakis, S. Distancing and Rapproching: Local Communities and Monuments in the Aegean Sea-A Case Study from the Island of Naxos. Conserv. Manag. Archaeol. Sites 2013, 15, 76-93. [CrossRef]

35. Taylor, M.N. Intangible Heritage Governance, Cultural Diversity, Ethno-Nationalism. Focaal 2009, 41-58. [CrossRef]

36. Winter, T. Beyond Eurocentrism? Heritage Conservation and the Politics of Difference. Int. J. Herit. Stud. 2014, 20, 123-137. [CrossRef]

37. Charters | Australia ICOMOS. Available online: https://australia.icomos.org/publications/charters/ (accessed on 3 August 2018).

38. Mason, R. Assessing Values in Conservation Planning: Methodological Issues and Choices. In Assessing the Values of Cultural Heritage; The Getty Conservation Institute: Los Angeles, LA, USA, 2002; pp. 5-30.

39. ICOMOS. The Declaration of Amsterdam; ICOMOS: Charenton-le-Pont, France, 1975.

40. Santiago de Compostela Declaration. Available online: https://rm.coe.int/16806f57d61987 (accessed on 1 July 2018).

41. CoE. European Landscape Convention of the Council of Europe/Official Website. Available online: https: / /www.coe.int/en/web/landscape (accessed on 2 July 2018).

42. UNESCO. Convention for the Safeguarding of the Intangible Cultural Heritage. Available online: https:/ / ich.unesco.org/en/ convention (accessed on 30 June 2018).

43. CoE. European Landscape Convention; CoE: Strasbourg Cedex, France, 2000; p. 8.

44. Lekakis, S. Social and Economic Trends in Cultural Heritage. Heritage Management at the Local Level. The Case of the Aegean and the Island of Naxos; National and Kapodistrian University of Athens: Athens, Greece, 2013.

45. Brundtland, G.H. Our Common Future: Report of the World Commission on Environment and Development. 1987. Available online: http:/ / un-documents.net/our-common-future.pdf (accessed on 30 June 2018).

46. UNESCO. Rio Declaration on Environment and Development. Available online: https://ich.unesco.org/en/ convention (accessed on 30 June 2018).

47. United Nations. United Nations Conference on Environment \& Development: Agenda 21. 1992. Available online: https:/ / sustainabledevelopment.un.org/content/documents/Agenda21.pdf (accessed on 30 June 2018).

48. Nurse, K. Culture as the Fourth Pillar of Sustainable Development. Culture 2006, 11, 32-48.

49. Cuthill, M.; Fien, J. Capacity Building: Facilitating Citizen Participation in Local Governance. Aust. J. Public Adm. 2005, 64, 63-80. [CrossRef]

50. UNESCO. Conferencia Mundial Sobre Politicas Culturales; Informe Final; UNESCO: Paris, France, 1982; p. 232.

51. UNESCO. World Decate for Cultural Development 1988-1997: Plan of Action; UNESCO: Paris, France, 1990.

52. Herzfeld, M. The Absent Presence: Discourses of Crypto-Colonialism. South Atl. Q. 2002, 101, 899-926. [CrossRef]

53. Nicholas, G. It's Taken Thousands of Years, but Western Science Is Finally Catching up to Traditional Knowledge. The Conversation, 15 February 2018.

54. Mainstreaming Indigenous Knowledge Systems. Available online: https://www.uwc.ac.za/News/Pages/ Mainstreaming-Indigenous-Knowledge-Systems-.aspx (accessed on 30 June 2018).

55. ICOMOS. The Nara Document on Authenticity. Knowl. Creat. Diffus. Util. 1994, 309, 9-12.

56. Smith, C.; Wobst, H.M. (Eds.) Indigenous Archaeologies: Decolonising Theory and Practice; Routledge: Los Angeles, LA, USA, 2004.

57. Smith, A. Archaeology, Local History and Community in French Polynesia. World Archaeol. 2010, 42, 367-380. [CrossRef] 
58. Steiner, L.; Frey, B.S. Imbalance of World Heritage List: Did the UNESCO Strategy Work? Economics Working Paper No. 14; University of Zurich: Zürich, Switzerland, 2011.

59. Unesco. 2015. Available online: unesdoc.unesco.org/images/0024/002448/244834e.pdf (accessed on 1 July 2018).

60. De Merode, E.; Smeets, R.; Westrik, C. (Eds.) Conclusions and Recommendations of the Conference. In Linking Universal and Local Values: Managing a Sustainable Future for World Heritage; UNESCO World Heritage Centre: Paris, France, 2004; pp. 165-168.

61. Kakadu Board of Management. Kakadu National Park Management Plan 2016-2026; Director of National Parks: Canberra, Australia, 2007.

62. Poulios, I. Discussing Strategy in Heritage Conservation. J. Cult. Herit. Manag. Sustain. Dev. 2014, 4, 16-34. [CrossRef]

63. Stovel, H.; Stanley-Price, N.; Killick, R. (Eds.) Conservation of Living Religious Heritage. In Conservation of Living Religious Heritage: Papers from the ICCROM 2003 Forum on Living Religious Heritage: Conserving the Sacred; ICCROM: Rome, Italy, 2005; pp. 1-11.

64. Gellner, D. The Idea of Nepal-The Mahesh Chandra Regmi Lecture 2016; Martin Chautari: Kathmandu, Nepal, 2016.

65. Goda, K.; Kiyota, T.; Pokhrel, R.M.; Chiaro, G.; Katagiri, T.; Sharma, K.; Wilkinson, S. The 2015 Gorkha Nepal Earthquake: Insights from Earthquake Damage Survey. Front. Built Environ. 2015, 1, 8. [CrossRef]

66. Satyal, U. 85pc Heritage Monuments Yet to Be Rebuilt. Available online: https://thehimalayantimes.com/ kathmandu/85-per-cent-heritage-monuments-yet-to-be-rebuilt/ (accessed on 27 April 2018).

67. Bue, E. Lo. Buddhist Art and Architecture in Nepal. In Oxford Bibliographies—Buddhism; Oxford University Press: Oxford, UK, 2011; p. 216.

68. Gray, J. Architecture and Architechnē: Building and Revealing in High-Caste Nepalese Houses. South Asia J. South Asia Stud. 2011, 34, 89-112. [CrossRef]

69. Slusser, M.S. Nepal Mandala: A Cultural Study of the Kathmandu Valley; Princeton University Press: Princeton, NJ, USA, 1982.

70. Gellner, D. Language, Caste, Religion and Territory: Newar Identity Ancient and Modern. Eur. J. Sociol. 1986, 27, 102-148. [CrossRef]

71. Shrestha, B.G. The Newars: The Indegenous Population of the Kathmandu Valley in the Modern State of Nepal; Center for Nepal and Asian Studies: Kirtipur, Nepal, 1999; pp. 83-117.

72. Shaha, R. Ancient and Medieval Nepal. Kailash J. Himal. Stud. 1990, 16, 22-84.

73. Worden, R.L. Nepal and Bhutan: Country Studies; Federal Research Division, Library of Congress: Washington, DC, USA, 1993.

74. UNESCO. Kathmandu Valley_UNESCO World Heritage Centre. Available online: https:/ / whc.unesco. org/en/list/121 (accessed on 2 July 2018).

75. Khokhlov, Y. The Xi Xia Legacy in Sino-Tibetan Art of the Yuan Dynasty. Asian Art 2016. Available online: www.asianart.com/articles/xi-xia/xi-xia.pdf (accessed on 15 June 2018).

76. Chan, H. Siting by Bowshot: A Mongolian Custom and Its Sociopolitical and Cultural Implications. Asia Major 1991, 4, 53-78.

77. Shrestha, D.B.; Singh, C.B. The History of Ancient and Medieval Nepal; HMG Press: Kathmandu, Nepal, 1972.

78. Malla, K.P. The Earliest Dated Document in Newari: The Palmleaf from Uku Bahah. Kailash 1990, 16, 15-25.

79. Shrestha, B.G. The Sacred Town of Sankhu: The Anthropology of Newar Ritual, Religion and ...: EBSCOhost; Cambridge Scholars Publishing: Newcastle, UK, 2012.

80. Quigley, D. The Guthi Organizations of Dhulikhel Shresthas. Kailash 1985, 12, 5-61.

81. Toffin, G. From Kin to Caste the Role of Guthi s in Newar; The Mahesh Chandra Regmi Lecture; Social Science Baha: Kathmandu, Nepal, 2005.

82. Joshi, J. Preserving the Hiti, Ancient Water Spout System of Nepal. In Proceedings of the Fabric, Threads of Conservation, Australia ICOMOS Conference, Adelaide, Australia, 5-8 November 2015.

83. Maharjan, M. Conflict in World Heritage Sites of Kathmandu Valley: A Case Study on the Conservation of Private Houses in Three Durbar Squares. Nepal Tour. Dev. Rev. 2013, 2, 87-104. [CrossRef]

84. Pradhananga, N.; Shrestha, K.K.; Dee, J. Sustaining Indigenous Heritage: Learning from the Guthi System in Nepal. In Proceedings of the New Zealand Geographical Society Conference, Christchurch, New Zealand, 5-8 July 2010; pp. 1-28. 
85. Adhikari, J. Land Reform in Nepal: Problems and Prospects; ActionAid: Kathmandu, Nepal, 2008.

86. Toffin, G. Imagination and Realities: Nepal between Past and Present, 1st ed.; Androit: Delhi, India, 2016.

87. Chiaro, G.; Kiyota, T.; Pokhrel, R.M.; Goda, K.; Katagiri, T.; Sharma, K. Reconnaissance Report on Geotechnical and Structural Damage Caused by the 2015 Gorkha Earthquake, Nepal. Soils Found. 2015, 55, 1030-1043. [CrossRef]

88. Weiler, K.M.L. The Neoclassical Residences of the Newars in Nepal; Heidelberg University: Heidelberg, Germany, 2009.

89. Upreti, B.C. The Maoist Insurgency in Nepal. South Asian Surv. 2006, 13, 35-50. [CrossRef]

90. Do, Q.-T.; Iyer, L. Geography, Poverty and Conflict in Nepal. J. Peace Res. 2010, 47, 735-748. [CrossRef]

91. How Political Instability Affected Nepal's Disaster Preparedness. Available online: http://www.dw.com/ en/how-political-instability-affected-nepals-disaster-preparedness/a-18411259 (accessed on 28 April 2018).

92. Gellner, D. The 2013 Elections in Nepal. Asian Aff. 2014, 45, 243-261. [CrossRef]

93. Two Years after the Earthquake, Why Has Nepal Failed to Recover? Available online: http: / theconversation. com/two-years-after-the-earthquake-why-has-nepal-failed-to-recover-77552 (accessed on 28 April 2018).

94. Shrestha, S.K. Average Bid Method-An Alternative to Low Bid Method in Public Sector Construction Procurement in Nepal Low Bid Method. J. Inst. Eng. 2014, 10, 125-129. [CrossRef]

95. Ojha, A. Concrete Wall around Rani Pokhari Draws Flak-Capital-The Kathmandu Post. Available online: http:/ / kathmandupost.ekantipur.com/news/2017-12-20/concrete-wall-around-rani-pokharidraws-flak.html (accessed on 22 December 2017).

96. Mathema, P. Contractors Threaten Nepal's Heritage. Available online: http:/ /www.gulf-times.com/story/ 539799/Contractors-threaten-Nepal-s-heritage (accessed on 4 June 2018).

97. Pradhananga, S.B. The Tussle for Kasthamandap. Available online: http:/ /kathmandupost.ekantipur.com/ news /2017-07-01/the-tussle-for-kasthamandap.html (accessed on 27 June 2018).

98. UNESCO Concerned about Inappropriate Rebuilding of Ranipokhari. Available online: http:/ / kathmandupost.ekantipur.com/news/2016-09-01/unesco-concerned-about-inappropriaterebuilding-of-ranipokhari.html (accessed on 4 June 2018).

99. Erich Theophile; Cynthia Rosenfeld. The Kathmandu Valley Preservation Trust. In Who Owns the Past? Cultural Policy, Cultural Property, and the Law; Gibbon, K.F., Ed.; Rutgers University Press: New Brunswick, NJ, USA, 2005.

100. Kathmandu Valley Preservation Trust. Available online: https://kvptnepal.org/2017eqresponsecampaign/ (accessed on 29 April 2018).

101. Gaddi Baithak Restoration Project. Available online: http://miyamotointernational.com/gaddi-baithakrestoration-project-us-embassy/ (accessed on 22 January 2018).

102. Zhang, Y. China Will Restore Nepali Heritage Site. Available online: http://usa.chinadaily.com.cn/epaper/ 2017-05/05/content_29219527.htm (accessed on 18 November 2017).

103. Slusser, M.S.; Vajrācārya, G. Two Medieval Nepalese Buildings: An Architectural and Cultural Study. Artibus Asiae 1974, 36, 169-218. [CrossRef]

104. Coningham, R.A.; Acharya, K.P.; Davis, C.E.; Kunwar, R.B.; Simpson, I.A.; Schmidt, A.; Tremblay, J.C. Preliminary Results of Post-Disaster Archaeological Investigations at the Kasthamandap and within Hanuman Dhoka, Kathmandu Valley UNESCO World Heritage Property (Nepal). Anc. Nepal 2016, 191, 28-51.

105. Preserving the Intangible. Available online: http://nepalitimes.com/article/Nepali-Times-Buzz/savingthe-intangible,3303 (accessed on 3 October 2017).

106. Alok Tuladhar. Righting Reconstruction Gone Wrong. Available online: http:/ / nepalitimes.com/article/ Nepali-Times-Buzz/righting-heritage-reconstruction-gone-wrong,3670 (accessed on 18 November 2017).

107. Ayoubi, A. Community-based Conservation of the Sacred Living Heritage at the Bauddhanath Monument Zone, Kathmandu Valley World Heritage Site, Nepal. Available online: http://iflaonline.org/2015/06/ community-based-conservation-of-the-sacred-living-heritage-at-the-bauddhanath-monument-zonekathmandu-valley-world-heritage-site-nepal/ (accessed on 4 August 2018).

108. Choden, T. Traditional Forms of Volunteerism in Bhutan; The Centre for Bhutan Studies: Thimpu, Bhutan, 2003.

109. Risal, D. Kasthamandap: Microcosm of Kathmandu's Living Culture and Storied History. Available online: http:/ / softdevelop.com/articles/kasthamandap/kasthamandap.pdf (accessed on 25 September 2017). 
110. Reconstruction of Kasthamandap Temple Begins. Available online: https://thehimalayantimes.com/ kathmandu/reconstruction-of-kasthamandap-temple-begins / (accessed on 28 June 2018).

111. Dave. Reconstructing the Ashok Stupa in Thamel. Available online: https://www.thelongestwayhome. $\mathrm{com} / \mathrm{blog} / \mathrm{nepal} /$ reconstructing-the-ashok-stupa-in-thamel/ (accessed on 29 April 2018).

112. Pradhananga, S. Heritage Reconstruction 2.0. Available online: http://kathmandupost.ekantipur.com/ news / 2017-03-18/heritage-reconstruction-20.html (accessed on 8 December 2017).

113. Delgado-Serrano, M.M. Trade-Offs between Conservation and Development in Community-Based Management Initiatives. Int. J. Commons 2017, 11, 969-991. [CrossRef]

114. Murray, G.; Agyare, A. Religion and Perceptions of Community-Based Conservation in Ghana, West Africa. PLoS ONE 2018, 13, 1-7. [CrossRef] [PubMed]

115. Leavesley, M.G.; Minol, B.; Kop, H.; Kewibu, V.H. Cross-Cultural Concepts of Archaeology: Kastom, Community, Education and Cultural Heritage Management in Papua New Guinea. Public Archaeol. 2005, 4, 3-13. [CrossRef]

116. Aswani, S.; Lemahieu, A.; Sauer, W.H.H. Global Trends of Local Ecological Knowledge and Future Implications. PLoS ONE 2018, 13, e0195440. [CrossRef] [PubMed]

117. Hutchings, E. Uluru-Kata Tjuta National Park: Management Plan 2010-2020; Director of National Parks: Canberra, Australia, 2010.

118. Wensing, E.; Porter, L. Unsettling Planning's Paradigms: Towards a Just Accommodation of Indigenous Rights and Interests in Australian Urban Planning? Aust. Plan. 2016, 53, 91-102. [CrossRef]

119. Lekakis, S. (Ed.) Cultural Heritage in the Realm of the Commons; Ubiquity Press: London, UK, 2018.

120. Ostrom, E.; Hess, C. Understanding Knowledge as a Commons; MIT Press: Cambridge, MA, USA, 2007.

121. Helfrich, S.; Bollier, D. Digital Commons. In Degrowth: A Vocabulary for a New Era; D'Alisa, G., Demaria, F., Kallis, G., Eds.; Routledge: New York, NY, USA, 2015; pp. 75-78.

122. Kostakis, V. Commons-Based Peer Production and the Neo-Weberian State: Synergies and Interdependencies. Halduskultuur 2011, 12, 146-161.

(C) 2018 by the authors. Licensee MDPI, Basel, Switzerland. This article is an open access article distributed under the terms and conditions of the Creative Commons Attribution (CC BY) license (http:/ / creativecommons.org/licenses/by/4.0/). 